\title{
Iron and Copper Complexes of Tetraphenyl-m-benziporphyrin: Reactivity of the Internal C-H Bond
}

\author{
Chen-Hsiung Hung, ${ }^{*}, \dagger$ Fei-Chien Chang, ${ }^{\dagger}$ Cheng-Yu Lin, ${ }^{\dagger}$ Krystyna Rachlewicz, ${ }^{\ddagger}$ Marcin Stępień, ${ }^{\ddagger}$ \\ Lechosław Latos-Grażyński, ${ }^{*}$, Gene-Hsiang Lee, ${ }^{\S}$ and Shie-Ming Peng"
}

\begin{abstract}
Department of Chemistry, National Changhua University of Education, Changhua 50058, Taiwan, Department of Chemistry, University of Wrocław, 14 F. Joliot-Curie St., Wrocław 50 383, Poland, Instrumentation Center, National Taiwan University, Taipei, Taiwan, and Department of Chemistry, National Taiwan University, Taipei, Taiwan
\end{abstract}

Received February 12, 2004

Iron and copper complexes of tetraphenyl-m-benziporphyrin (TP$\mathrm{mBPH}) \mathrm{H}$ have been prepared and structurally characterized. The iron system, (TPmBPH)Fe" Br, contains a high-spin $\mathrm{Fe}(\mathrm{II})$ center. In the solid state the complex forms dimeric units linked by weak $\mathrm{CH} \cdots \mathrm{Br}$ hydrogen bonds. The $\mathrm{Cu}$ complex contains a tetrameric copper cluster with a $\mathrm{Cu}_{2} \mathrm{Cl}_{4}{ }^{2-}$ unit bridging two $\left[(\mathrm{TPmBPCl}) \mathrm{Cu}^{\prime \prime}\right]^{+}$ fragments. The formation of (TPmBPCl) $\mathrm{H}$ represents an example of copper-catalyzed chlorination on the internal carbon atom of (TPmBPH)H.

The idea of replacing a pyrrole ring in the porphyrin macrocycle with a carbocycle (heterocarbocycle) to exploit the coordinating properties of porphyrin cores has initiated studies on carbaporphyrins, a new class of porphyrin analogues. ${ }^{1-4}$ Recently, it was shown that $\mathrm{N}$-confused tetraphenylporphyrin $(\mathrm{CTPPH}) \mathrm{H}_{2}$ can stabilize unusual metal oxidation states $^{5}$ and provides a unique environment for studying the formation and reactivity of organometallic metal-carbon bonds. ${ }^{6-8}$ It has also been found that the internal $\mathrm{C}-\mathrm{H}$ bond of the $(\mathrm{CTPP} H) \mathrm{H}_{2}$ system is susceptible to substitution reactions. The products of alkylation, ${ }^{9}$ nitra-

\footnotetext{
* Authors to whom correspondence should be addressed. E-mail: chhung@cc.ncue.edu.tu (C.-H.H.); 11g@wchuwr.chem.uni.wroc.pl (L.L.-G.).

National Changhua University of Education

$\doteqdot$ University of Wrocław.

$\S$ Instrumentation Center, National Taiwan University.

"Department of Chemistry, National Taiwan University.

(1) Furuta, H.; Asano, T.; Ogawa, T. J. Am. Chem. Soc. 1994, 116, 767

(2) Chmielewski, P. J.; Latos-Grażyński, L.; Rachlewicz, K.; Głowiak, T. Angew. Chem., Int. Ed. Engl. 1994, 33, 779.

(3) Berlin, K.; Breitmaier, E. Angew. Chem., Int. Ed. Engl. 1994, 33, 1246.

(4) Lash, T. D.; Chaney, S. T. Angew. Chem., Int. Ed. Engl. 1997, 36, 839.

(5) Furuta, H, Ogawa, T.; Uwatoko, Y.; Araki, K. Inorg. Chem. 1999, $38,2676$.

(6) Chen, W.-C.; Hung, C.-H. Inorg. Chem. 2001, 40, 5070.

(7) Bohle, D. S.; Chen, W.-C.; Hung, C.-H. Inorg. Chem. 2002, 41, 3334.

(8) Hung, C.-H.; Chen, W.-C.; Lee, G.-H.; Peng, S.-M. Chem. Commun. 2002, 1516.

(9) Chmielewski, P. J.; Latos-Grażyński, L, Glowiak, T. J. Am. Chem. Soc. 1996, 118, 5690.
}

4118 Inorganic Chemistry, Vol. 43, No. 14, 2004 tion, ${ }^{10}$ internal fusion, ${ }^{11}$ and cyanation ${ }^{12}$ have been reported to date. More recently, tetraaryl- $m$-benziporphyrin and its para isomer, which have a pyrrole ring replaced with a benzene ring, have been prepared and structurally characterized. ${ }^{13,14}$ Both benziporphyrins have already been shown to coordinate selected metal(II) ions. ${ }^{13-15}$ In the reactions of $m$-tetraphenylbenziporphyrin with silver salts, the pyridination $^{16}$ and acetoxylation products ${ }^{14}$ have been isolated. Reactions of 22-acetoxy- $m$-benziporphyrin with zinc(II) or cadmium(II) give metal complexes containing an unmodified acetoxy substituent while the reactions with nickel(II) or palladium(II) cleave the Ac-O bond and form 22-hydroxy$m$-benziporphyrin species. ${ }^{17}$ The unusual reactivity of the internal carbon has inspired us to further exploit the chemistry of carbaporphyrins. Herein we report the syntheses and characterization of iron and copper complexes of tetraphenyl- $m$-benziporphyrin (Scheme 1). Interestingly, the reaction of copper(II) chloride with $m$-benziporphyrin yields a 22-chloro- $m$-benziporphyrin complex from a chlorination reaction of the internal carbon on the $m$-benziporphyrin core.

When refluxing a THF solution of free base $(\mathrm{TP} m \mathrm{BPH}) \mathrm{H}$ and $\mathrm{FeBr}_{2}$ for $4 \mathrm{~h}$ in the presence of a few drops of 2,6lutidine under anaerobic conditions, (TP $m \mathrm{BP} H) \mathrm{Fe}^{\mathrm{II}} \mathrm{Br}(\mathbf{2})$ can be worked up in $71 \%$ yield. ${ }^{18}$ The final product gives a Soret band at $431 \mathrm{~nm}$ and $Q$ bands at 770 and $860 \mathrm{~nm}$ (Figure 1). Compared with the free base of $(\mathrm{TP} m \mathrm{BP} H) \mathrm{H}$ the Soret band is red-shifted only slightly but the bathochromic shift of the $Q$ bands is significant. The compound is relatively stable toward dioxygen in contrast to the instantaneous reaction with $\mathrm{O}_{2}$ in the case of $(H C T P P H) \mathrm{Fe}^{\mathrm{II}} \mathrm{Br} .{ }^{19}$

(10) Ishikawa, Y.; Yoshida, I.; Akaiwa, K.; Koguchi, E.; Sasaki, T.; Furuta H. Chem. Lett. 1997, 453.

(11) Furuta, H.; Ishizuka, T.; Osuka, A.; Ogawa, T. J. Am. Chem. Soc. 1999, 121, 2945.

(12) Xiao, Z.; Patrick, B. O.; Dolphin, D. Chem. Commun. 2003, 1062.

(13) Stẹpień, M.; Latos-Grażyński, L. J. Am. Chem. Soc. 2002, 124, 3838.

(14) Stępień, M.; Latos-Grażyński, L. Chem. Eur. J. 2001, 7, 5113.

(15) Stępień, M.; Latos-Grażyński, L.; Szterenberg. L.; Panek, J. Latajka, Z. J. Am. Chem. Soc. 2004, 126, 4566.

(16) Stępień, M.; Latos-Grażyński, L. Org. Lett. 2003, 5, 3379.

(17) Stȩpień, M.; Latos-Grażyński, L. Inorg. Chem. 2003, 42, 6183.

10.1021/ic049821I CCC: $\$ 27.50$ @ 2004 American Chemical Society Published on Web 06/05/2004 


\section{COMMUNICATION}

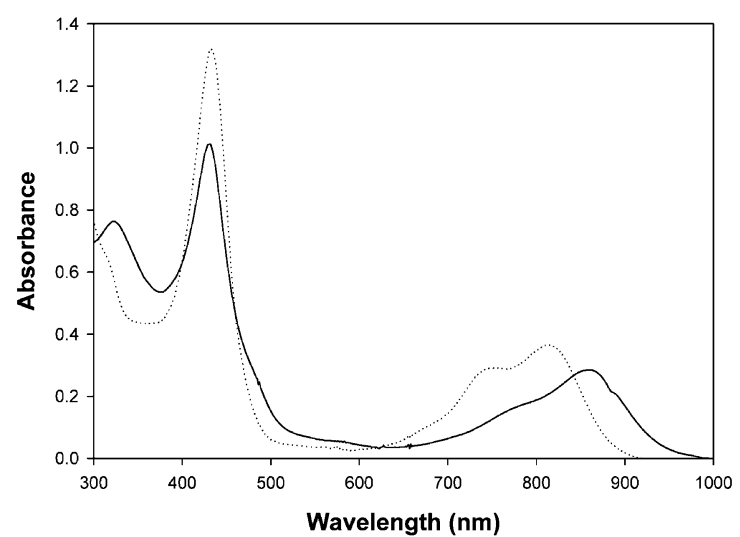

Figure 1. The absorption spectra of $\mathbf{2}(-)$ and $\mathbf{3}(\cdots)$.

\section{Scheme 1}

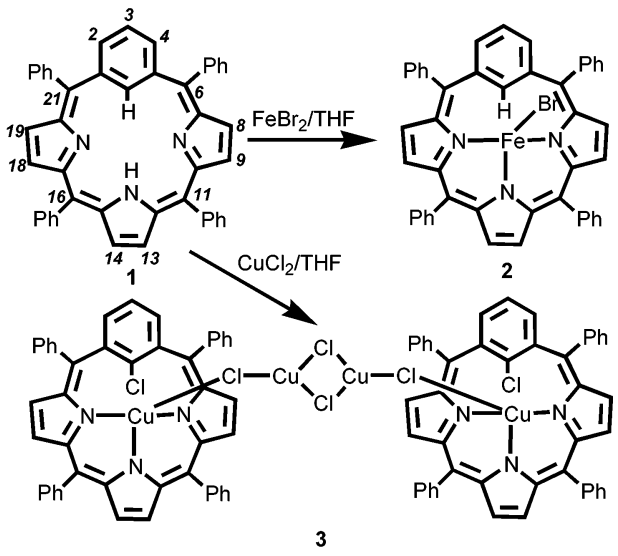

A magnetic susceptibility measurement performed in solution for $\mathbf{2}$ using the Evans method gives an effective magnetic moment of $4.65 \mu_{\mathrm{B}}$. The value is in the range for a high-spin $\mathrm{Fe}(\mathrm{II})$ center.

As shown in Figure 2, the $\beta$-pyrrolic protons of $\mathbf{2}$ are located at 49.4, 21.1, and $6.5 \mathrm{ppm}$ at $293 \mathrm{~K}$ as identified by ${ }^{2} \mathrm{H}$ NMR for $\left(\mathrm{TP} m \mathrm{BPH}-d_{6}\right) \mathrm{Fe}^{\mathrm{II}} \mathrm{Br}$. These values are close to those recently reported for high-spin nickel(II) complexes of 22-acetoxybenziporphyrin ${ }^{17}$ and tetraphenyl- $m$-benziporphyrin. ${ }^{15}$ The hydrogens on the $m$-phenylene ring have been identified by default at 22-H, 440; 2,4-H, 65.8; 3-H, -33.2 ppm $(298 \mathrm{~K})$. Interestingly, the $440 \mathrm{ppm}$ shift of the inner $\mathrm{C}-\mathrm{H}$ proton is much smaller than the corresponding shift observed for $(H C T P P H) \mathrm{Fe}^{\mathrm{II}} \mathrm{Br}(812 \mathrm{ppm}, 298 \mathrm{~K})^{20}$ but similar to the value for (TPmBPH$) \mathrm{Ni}^{\mathrm{II}} \mathrm{Cl}(386 \mathrm{ppm}, 298 \mathrm{~K}) .^{15}$ An agostic mechanism of spin density transfer, described

(18) Absorption spectrum $\left(\mathrm{CH}_{2} \mathrm{Cl}_{2}\right)\left[\lambda_{\max }, \mathrm{nm}\left(\log \epsilon, \mathrm{M}^{-1} \mathrm{~cm}^{-1}\right)\right]: 339$ (4.06), 431 (4.34), 770 (3.53, sh), 860 (3.81). MS (ESI): $\mathrm{m} / z=760.9$ (calcd $\mathrm{m} / \mathrm{z}=760.1$ for $\left.\mathrm{M}+\mathrm{H}^{+}\right), 680.4\left(\right.$ calcd $\mathrm{m} / \mathrm{z}=680.2$ for $\mathrm{M}^{+}$ $-\mathrm{Br}), 626.5$ (calcd $\mathrm{m} / \mathrm{z}=625.3$ for $\left.\mathrm{M}+\mathrm{H}^{+}-\mathrm{Br}-\mathrm{Fe}\right) .{ }^{1} \mathrm{H}$ NMR $\left(\mathrm{CD}_{2} \mathrm{Cl}_{2}\right): 400(1 \mathrm{H}, 22-\mathrm{H}), 65.8(2 \mathrm{H}, 2,4-\mathrm{H}), 49.4(2 \mathrm{H}$, pyrr $), 21.1$ (2 H, pyrr), 6.9 ( $2 \mathrm{H}$, pyrr), $-33.2(2 \mathrm{H}, 3-\mathrm{H})$. Crystallographic data for 2: $\mathrm{C}_{53} \mathrm{H}_{38} \mathrm{BrFeN}_{3}, T=150(2) \mathrm{K}, \mathrm{MW}=852.62$, triclinic, space group $\mathrm{P} 1, a=11.0498(13) \AA$ $\AA, \alpha=78.544(2)^{\circ}, \beta=79.527(2)^{\circ}, \gamma=77.699(2)^{\circ} V=2003.0(4)$ $\AA^{3}, \mathrm{Z}=2, D_{\mathrm{c}}=1.414 \mathrm{Mg} / \mathrm{m}^{-3}, \lambda=0.71073 \AA, \mu=1.416 \mathrm{~mm}^{-1}$, $F(000)=876$. The structure was solved by direct methods and refined by least squares against $F^{2}$ to $R_{1}=0.0414\left(\mathrm{w} R_{2}=0.0788\right)$ and $S_{\mathrm{GOF}}$ $=0.957$.

(19) Rachlewicz, K.; Wang, S.-L.; Ko, C.-L.; Hung, C.-H.; Latos-Grażyński, L. J. Am. Chem. Soc. 2004, 126, 4420.

(20) Rachlewicz, K.; Wang, S.-L.; Peng, C.-H.; Hung, C.-H.; LatosGrażyński, L. Inorg. Chem. 2003, 42, 7348.
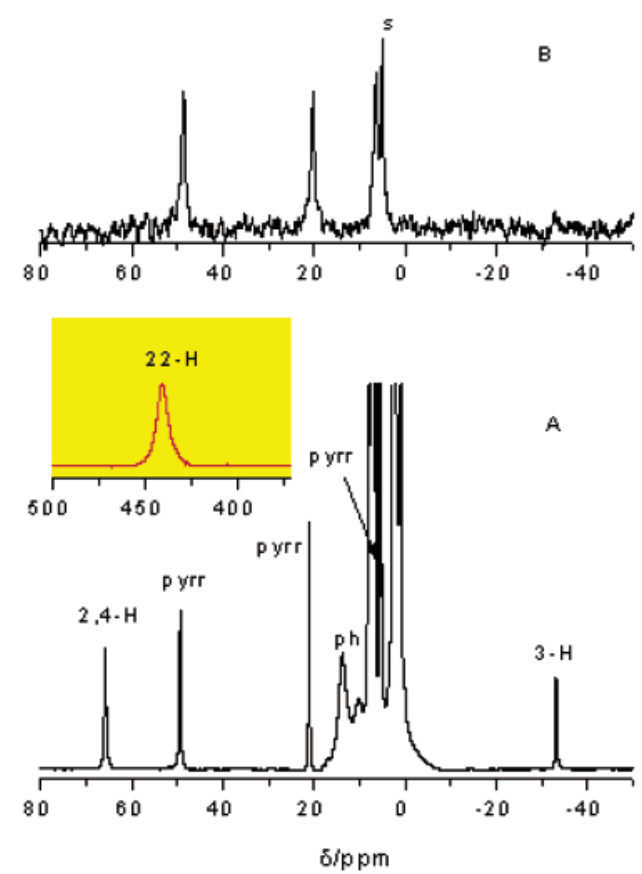

Figure 2. NMR spectra of iron(II) tetraphenyl-m-benziporphyrin: (A) $(\mathrm{TP} m \mathrm{BP} H) \mathrm{Fe}^{\mathrm{II}} \mathrm{Br}\left({ }^{1} \mathrm{H}\right.$ NMR, dichloromethane-d $\left.d_{2}, 298 \mathrm{~K}\right)$; (B) (TPmBPH$\left.d_{6}\right) \mathrm{Fe}{ }^{\mathrm{II}} \mathrm{Br}\left({ }^{2} \mathrm{H} \mathrm{NMR}\right.$, dichloromethane, $\left.298 \mathrm{~K}\right)$. Inset in trace A presents the downfield region with the $22-\mathrm{H}$ resonance. Peak labels follow the systematic numbering of the porphyrin ring or denote proton groups: pyrr, pyrrole ring; ph, meso-phenyl; s, solvent.

previously for $(\mathrm{TP} m \mathrm{BP} H) \mathrm{Ni}^{\mathrm{II}} \mathrm{Cl}$, explains the shifts of $(\mathrm{TP} m \mathrm{BP} H) \mathrm{Ni}^{\mathrm{II}} \mathrm{Cl}$ as resulting from electron donation from the $\mathrm{CH}$ bond to the metal. ${ }^{15}$

The reaction between $\mathrm{Cu}(\mathrm{II})$ and $(\mathrm{TP} m \mathrm{BPH}) \mathrm{H}$ has been carried out under much milder conditions. Using $\mathrm{CuCl}_{2}$ as the metal carrier under anaerobic conditions at room temperature in the absence of base, $\left[(\mathrm{TP} m \mathrm{BPCl}) \mathrm{Cu}^{\mathrm{II}}\right]_{2}\left(\mathrm{Cu}_{2}^{\mathrm{I}} \mathrm{Cl}_{4}\right)$ (3) can be readily obtained in $75 \%$ yield. ${ }^{21}$ The UV-vis spectrum of $\mathbf{3}$ (Figure 1) resembles that of $\mathbf{2}$ with the $Q$ band slightly blue-shifted. The elemental analysis suggested that the compound is a tetranuclear complex with a $\left[\mathrm{Cu}_{2} \mathrm{Cl}_{4}\right]^{2-}$ unit bridging two copper(II) benziporphyrins. Importantly, the mass peak at $m / z, 721.2$ suggests that a chlorination reaction proceeds cleanly according to eq 1 . This reactivity resembles the silver-mediated 22-substitutions observed earlier for the reactions of $(\mathrm{TP} m \mathrm{BP} H) \mathrm{H}$ with acetate ions ${ }^{14}$ and pyridine. ${ }^{16}$

$$
\begin{aligned}
& 2(\mathrm{TP} m \mathrm{BP} H) \mathrm{H}+4 \mathrm{Cu}^{\mathrm{II}} \mathrm{Cl}_{2} \rightarrow \\
& \left.\quad(\mathrm{TP} m \mathrm{BPCl}) \mathrm{Cu}^{\mathrm{II}}\right]_{2}\left(\mathrm{Cu}_{2}^{\mathrm{I}} \mathrm{Cl}_{4}\right)+2 \mathrm{HCl}
\end{aligned}
$$

The structures of both $\mathbf{2}$ and $\mathbf{3}$ are confirmed by X-ray structural analysis. The iron complex crystallized in the $P \overline{1}$

(21) Absorption spectrum $\left(\mathrm{CH}_{2} \mathrm{Cl}_{2}\right)\left[\lambda_{\max }, \mathrm{nm}\left(\log \epsilon, \mathrm{M}^{-1} \mathrm{~cm}^{-1}\right)\right]: 433$ (5.12), 757 (4.46, sh), 814 (4.56). MS (ESI): $\mathrm{m} / \mathrm{z}=721.2$ (calcd $\mathrm{m} / \mathrm{z}$ $=721.1$ for $[\mathrm{Cu}(\mathrm{TP} m \mathrm{BPCl})]^{+}$. Anal. Calcd for $\mathrm{Cu}_{4} \mathrm{Cl}_{6} \mathrm{~N}_{6} \mathrm{C}_{92} \mathrm{H}_{58} \cdot \mathrm{CH}_{2}-$ $\mathrm{Cl}_{2} \cdot \mathrm{C}_{6} \mathrm{H}_{14}: \mathrm{N}, 4.45 ; \mathrm{C}, 63.06 ; \mathrm{H}, 3.95$. Found: $\mathrm{N}, 4.78 ; \mathrm{C}, 64.92 ; \mathrm{H}$ 3.73. Crystallographic data for 3: $\mathrm{C}_{48} \mathrm{H}_{33} \mathrm{Cl}_{7} \mathrm{Cu}_{2} \mathrm{~N}_{3}, T=150(1) \mathrm{K}$, $\mathrm{MW}=1027.00$, monoclinic, space group $P 2_{1} / c, a=14.5784(5) \AA$, $b=25.0959(8) \AA, c=12.6346(5) \AA, \beta=108.462(1)^{\circ}, V=4384.6$ (3) $\AA^{3}, \mathrm{Z}=4, D_{\mathrm{c}}=1.556 \mathrm{Mg} / \mathrm{m}^{-3}, \lambda=0.71073 \AA, \mu=1.556 \mathrm{~mm}^{-1}$, $F(000)=2074$. The structure was solved by direct methods and refined by least squares against $F^{2}$ to $R_{1}=0.0588\left(\mathrm{w} R_{2}=0.1329\right)$ and $S_{\mathrm{GOF}}$ $=1.091$. 


\section{COMMUNICATION}

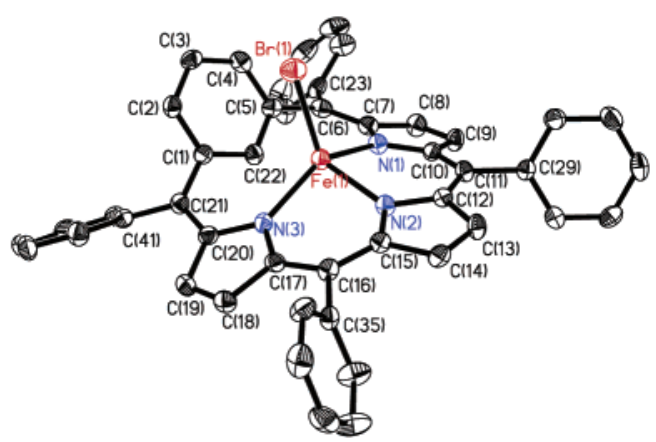

Figure 3. The crystal structure of $\mathbf{2}$ with $50 \%$ thermal ellipsoids.

space group with one solvate toluene per asymmetric unit (Figure 3). The iron center binds to three pyrrolic nitrogens and a bromide in a distorted tetrahedral structure. The bromide bends toward the $m$-phenylene ring and expands the angle of $\mathrm{N} 2-\mathrm{Fe} 1-\mathrm{Br} 1$ to $116.15(9)^{\circ}$. The distance of 2.073(3) $\AA$ for Fe1-N2 is slightly shorter than 2.131(3) and 2.141(3) $\AA$ for $\mathrm{Fe} 1-\mathrm{N} 1$ and $\mathrm{Fe} 1-\mathrm{N} 3$. The distances between iron and pyrrolic nitrogens are in the range for high-spin $\mathrm{Fe}(\mathrm{II})$ porphyrin complexes. ${ }^{22}$ The tripyrrolic fragment arranges in a dome-shaped geometry. The average deviation of three pyrrole rings and four meso-carbons from the three nitrogen plane is $0.35 \AA$. The iron sits 0.694(2) $\AA$ above the three nitrogen plane. The large deviation of iron from the porphyrin plane has been observed in five-coordinated iron(II) porphyrin complexes. ${ }^{22}$ As expected, the $m$-phenylene ring is tilted away from the mean porphyrin plane. The distances from iron to the inner carbon (C22) and inner hydrogen (H22) are 2.579(4) and 2.439(36) $\AA$, respectively. These distances are longer than the corresponding distances of 2.361 and $1.971 \AA$ in $(H C T P P H) \mathrm{Fe}^{\mathrm{II}} \mathrm{Br}$ wherein we confirmed the existence of an agostic interaction between $\mathrm{Fe}$ and the inner $\mathrm{C}-\mathrm{H}$ bond. ${ }^{8}$ Nevertheless, these values are small compared to the van der Waals contact ${ }^{23}$ and similar to those seen in chloronickel(II) $m$-benziporphyrin $(\mathrm{Ni} \cdots \mathrm{C} 22$, 2.549(3) $\AA$; $\mathrm{Ni} \cdots \mathrm{H} 22$ 2.40(3) $\AA$ ), ${ }^{15}$ and they evidence the formation of a weak agostic bond. Importantly, the angle between $\mathrm{Fe} 1-\mathrm{C} 22$ and the $m$-phenylene ring is $110.5^{\circ}$, which is much less than $126.2^{\circ}$ for $(H C T P P H) \mathrm{Fe}^{\mathrm{II}} \mathrm{Br}^{6}{ }^{6}$ In the crystal lattice, 2 forms a cyclic dimeric structure with mutual hydrogen bonding interactions between the axial bromides and $\mathrm{H} 3$ atoms on the $m$-phenylene rings (see Supporting Information).

The crystal of $\mathbf{3}$ belongs to the $P 2_{1} / c$ space group with the molecule located at a symmetry center. The tetranuclear complex (Figure 4) is a neutral compound, and four solvate dichloromethanes per tetranuclear complex are located in the unit cell.

(22) Scheidt, W. R.; Reed C. A. Chem. Rev. 1981, 81, 543.

(23) Bondi, A. J. Phys. Chem. 1964, 68, 441.

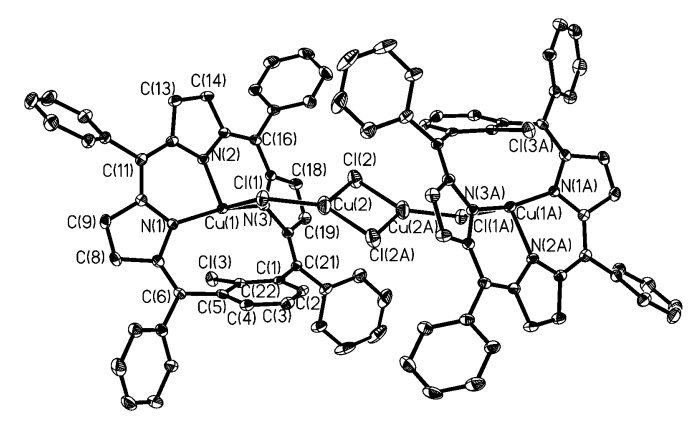

Figure 4. The crystal structure of $\mathbf{3}$ with $50 \%$ thermal ellipsoids which shows the tetranuclear complexes and $\mathrm{TP} m \mathrm{BPCl}$ cores.

In agreement with the elemental analysis described above, the copper complex is a tetranuclear complex with a bridging $\left[\mathrm{Cu}_{2} \mathrm{Cl}_{4}\right]^{2-}$ unit. The bridging ligand of $\left[\mathrm{Cu}_{2} \mathrm{Cl}_{4}\right]^{2-}$ is rare but has been reported in several structures including the recent one by Busch et al. ${ }^{24}$ The structure parameters of $\left[\mathrm{Cu}_{2} \mathrm{Cl}_{4}\right]^{2-}$ in $\mathbf{3}$ are comparable to the literature values. A chlorine atom on the $m$-phenylene moiety can be clearly identified with a distance of 1.751(3) $\AA$ for $\mathrm{C} 22-\mathrm{Cl} 3$. The $\mathrm{TP} m \mathrm{BPCl}$ moiety has a tilted $m$-phenylene ring and a saddle arrangement of the tripyrrolic unit. The average distance between copper and pyrrolic nitrogens of 1.976(3) $\AA$ agrees with the presence of a copper(II) ion in the carbaporphyrin central cavity. ${ }^{25}$ The distance between copper(II) and the inner carbon C22 is 2.698(5) $\AA$, which is significantly longer than the distance in $\mathbf{2}$.

In conclusion, iron and copper complexes of $m$-benziporphyrin have been prepared. The studies on the NMR spectroscopy and crystal structure of $\mathbf{2}$ suggest a weaker interaction between the iron center and internal $\mathrm{C}-\mathrm{H}$ for $\mathbf{2}$ compared with $(H C T P P H) \mathrm{Fe}^{\mathrm{II}} \mathrm{Br}$. The formation of a tetranuclear copper complex and the copper-assisted chlorination is unexpected but further demonstrates the versatile chemistry that can be carried out in carbaporphyrin systems.

Acknowledgment. This work was supported by the National Science Council of Taiwan under Grant NSC 922113-M-018-003 (C.-H.H.) and by the State Committee for Scientific Research of Poland (KBN) under Grant 4 T09A 14722 (L.L.-G. and M.S.). M.S. thanks the Foundation for Polish Science for financial support.

Supporting Information Available: Experimental procedures, spectroscopic data, VT plots for $\mathbf{2}$ in toluene- $d_{8}$, and X-ray crystallographic data for $\mathbf{2}$ and $\mathbf{3}$. This material is available free of charge via the Internet at http://pubs.acs.org.

IC049821L

(24) Rybak-Akimova, E. V.; Busch, D. H.; Kahol, P. K.; Pinto, N.; Alcock, N. W.; Clase, H. J. Inorg. Chem. 1997, 36, 510.

(25) Scheidt, W. R.; Turowska-Tyrk, I. Inorg. Chem. 1994, 33, 1314. 